\title{
1
}

\section{Humanitarian intervention today}

Humanitarian intervention - that is, military intervention aimed at saving innocent people in other countries from massive violations of human rights (primarily the right to life) - entered public consciousness around 1990 as never before in the course of the twentieth century. It has earned a central place in scholarly research and in the preoccupations of decision-makers and international organizations and has captured the imagination of the wider public in a fashion few other political subjects have achieved in the post-Cold War world. ${ }^{1}$ Ironically, it is in the limelight not due to its general acceptance but because of its controversial character, which has led to acrimonious debates. At the two ends of the scale there is, on the one hand, rejection, with the notion seen as nonsensical, an 'oxymoron', ${ }^{2}$ the hallmark of deceit and, on the other, its acceptance as one of the clearest manifestations of altruism, the epitome of human solidarity and compassion (the 'good Samaritan'), the willingness to face great risk and considerable loss to save the lives of 'strangers', with no gains.

Interestingly, rejection of, and sheer incredulity with, 'humanitarian intervention' is shared across the ideological spectrum, from realist scholarship in international relations to Marxism and other forms of leftist critique, as well as pacifism. From the realist line of reasoning, which has its origins in Thucydides, Machiavelli, Hobbes and Spinoza, so-called 'humanitarian' or other ethical concerns have no place in international politics and are damaging to rational foreign policy. More scathing is a critique from Carl Schmitt, who argued that 'war in the name of humanity, is not war for the sake of humanity, but a war wherein a particular state seeks to usurp a universal concept against its military opponent', identifying itself with humanity and denying it to the enemy. ${ }^{3} \mathrm{He}$ adds (as if he were a Marxist) that it has been used as 'an ideological instrument of imperialist expansion, and in its ethical-humanitarian form it is a specific vehicle of economic imperialism ... whoever invokes humanity wants to cheat'. ${ }^{4}$

The question of intervention for humanitarian reasons poses agonizing dilemmas. There is the tension between the sanctity of life (saving human beings) 
and the veneration of sovereignty and independence; and there is the tension between doing something salutary in a humanitarian crisis if the United Nations Security Council is paralysed and abuse in the name of humanitarianism by intervening states. Most liberals opt for saving lives ${ }^{5}$ and for intervening, exceptionally, even without the authorization of the United Nations, provided the intervention has gained wide international legitimacy and the plight is so appalling that the interest in global humanity overrides narrowly defined national interest. ${ }^{6}$ Realists of course discard ethics in foreign affairs (with exceptions, such as those realists who take seriously the "morality of states ${ }^{\text {'7) }}$ ) and regard only threats to vital interests worthy of intervention, and intervention for humanitarian reasons a delusion, or as bogus. Most leftist thinkers, such as Noam Chomsky, ${ }^{8}$ Edward Said, Tariq Ali, ${ }^{9}$ Jacques Derrida or Jean Baudrillard denounced the 1999 intervention in Kosovo and the whole idea of 'humanitarian intervention', as have other critical thinkers in more scholarly manner, such as Anne Orford, ${ }^{10}$ Antony Anghie ${ }^{11}$ and Costas Douzinas. ${ }^{12}$ For them, intervention is by definition abusive, the diktat of the powerful, a form of blatant neo-imperialism and neo-colonialism. But a minority of leftist thinkers, who put a premium on self-determination and saving the weak from the strong, are favourable to such interventions, albeit in very exceptional cases, such as Jürgen Habermas, ${ }^{13}$ Michael Walzer ${ }^{14}$ and the more controversial Bernard Kouchner, with his droit d'ingérence. ${ }^{15}$

Most international lawyers are opposed to such interventions, emphasizing state sovereignty and independence. There has, though, been a shift, which is far from insignificant, in that during the Cold War, among those opposed, the majority were against the whole notion, while in the post-Cold War era most are opposed to intervention only if it does not obtain UN authorization. Students of international relations are more nuanced, especially non-realists, ${ }^{16}$ with those in the field of international ethics, cosmopolitans in particular, who tend to be less burdened by sovereignty, supporting unilateral humanitarian intervention, followed more guardedly by communitarians, from Michael Walzer in the late 1970s onwards. ${ }^{17}$ They, together with international lawyers supportive of humanitarian intervention even without a UN mandate, disagree mainly as to the level of onslaught that warrants intervention, which ranges from systematic violations of fundamental human rights to a situation akin to genocide, ${ }^{18}$ and the point at which to intervene: early on or late in a conflict, when all attempts to stop the humanitarian plight peacefully have failed.

During the Cold War, humanitarian intervention was generally considered beyond the pale, although even then a minority of international lawyers supported armed intervention on humanitarian grounds. ${ }^{19}$ Some states, notably the US in the cases of the Dominican Republic (1965) and Grenada (1983), Belgium in Congo (1960-61), Belgium and the US in Congo (1964) or France in the Central African Republic (1979), had justified their actions on humanitarian grounds. But the near consensus is that only three military interventions qualify as humanitarian given 
that they put an end to widespread loss of life: India's intervention in East Pakistan (1971) (hundreds of thousands of civilians dead and almost nine million refugees fleeing to India), which led to the creation of Bangladesh; Vietnam's overthrow of the heinous Khmer Rouge regime under Pol Pot in Cambodia (1979) (with up to two million civilian deaths mainly from disease and malnutrition in forced labour camps); and the overthrow of Amin's odious regime in Uganda (with 300,000 citizens murdered by Amin's thugs) by Tanzania (1979). Interestingly, all three intervening states did not justify their action on humanitarian grounds (with the partial exception of India ${ }^{20}$ ) but on grounds of self-defence, and all three intervened mainly for instrumental reasons, especially Vietnam. The first two interventions faced heavy wind internationally, notably in the UN (especially the Vietnamese invasion), even though they both saved many lives. ${ }^{21}$

Following the end of the Cold War, the first post-bipolar decade witnessed unprecedented interventionism on humanitarian grounds: safe haven for the Kurds of northern Iraq (1991), Somalia (1992), Bosnia (1992-95), the intervention of the Economic Community Of West African States (ECOWAS) in Liberia (1990-96), the US-led intervention in Haiti (1994), French-led forces in Rwanda (1994), NATO's intervention in Serbia and Kosovo (1999) and the Australian-led intervention in East Timor (1999).

In Rwanda effective French intervention came very late, following three months of genocidal massacre by the Hutus of more than 800,000 Tutsis and many moderate Hutus. ${ }^{22}$ The peacemaking intervention of ECOWAS in Liberia headed by Nigeria ${ }^{23}$ and NATO's Kosovo/Serbia operation took place without authorization by the UN Security Council. NATO's Kosovo/Serbia operation gave rise to a heated discussion not only because of its lack of UN endorsement but also due to the choice of means (high-altitude aerial bombardment), which led to hundreds of civilian deaths, more intense ethnic cleansing by the repugnant Milosevic regime, thousands of refugees, considerable destruction of infrastructure and environmental pollution. ${ }^{24}$ Many had feared that this Kosovo precedent would open a Pandora's box but this did not come about, partly due to these unintended consequences. In the second part of 1999, the Australian-led peacekeeping operation in East Timor took place with UN sanction, with no mismatch between the military means and humanitarian ends, and it turned out to be peaceful. ${ }^{25}$ With the onset of the new millennium - and with ' $9 / 11$ ' and its repercussions as far as US priorities were concerned (the 'war on terror') - the idea of humanitarian intervention seemed to have 'evaporated', ${ }^{26}$ although there were at least two candidates, Sierra Leone and Sudan's Darfur. The next humanitarian interventions took place more than a decade later: the NATO-led operation in Libya (February-October 2011) and the French peacekeeping operation in the Central African Republic (December 2013), both authorized by the UN Security Council. ${ }^{27}$

In the wake of the Kosovo experience, UN Secretary-General Kofi Annan pondered: 'On the one hand is it legitimate for a regional organisation to use 
force without a UN mandate? On the other is it permissible to let gross and systematic violations of human rights, with grave humanitarian consequences, continue unchecked? ${ }^{28}$ Addressing the UN General Assembly in September 1999, he expressed his strong reservations about NATO's unauthorized intervention in Kosovo and Serbia but added: 'If in those dark days and hours leading to the genocide [in Rwanda] a coalition of States had been prepared to act in the defence of the Tutsi population, but did not receive prompt Council authorization, should such a coalition have stood aside and allowed the horror to unfold?'29 And he challenged the member-states to come up with a new vision of sovereignty. ${ }^{30}$

The Annan challenge was taken up by the Canadian-sponsored twelve-person International Commission on Intervention and State Sovereignty (ICISS), which responded by subsuming humanitarian intervention under the novel concept of 'responsibility to protect' ( $\mathrm{R}_{2} \mathrm{P}$ or RtoP). ${ }^{31}$ The aim of the $\mathrm{R}_{2} \mathrm{P}$ approach was to 'shift the terms of the debate'; ${ }^{32}$ it amounts to a 'rhetorical trick' of flipping the coin and shifting the emphasis from the controversial right to intervene for humanitarian reasons to the 'less confrontational idea of a responsibility to protect', ${ }^{33}$ but the substance remains the same.

In 2005 at intergovernmental level, the Outcome Document of the UN World Summit (15 September) made it a primary responsibility of states to protect their population against 'genocide, war crimes, crimes against humanity and ethnic cleansing'; if they fail to do so, a 'timely and decisive response' becomes the responsibility of the international community. The ICISS had suggested that the permanent members of the Security Council refrain from using the veto in such cases as long as their vital interests are not at stake but this was unacceptable to the US, Russia and China. ${ }^{34}$ The first test case of $\mathrm{R}_{2} \mathrm{P}$ was the intervention in Libya. ${ }^{35}$

Given the situation during the Cold War and the interventionism of the 1990 os and the ongoing debate, the general impression is that humanitarian intervention is basically a recent phenomenon, but in fact the concept of humanitarian intervention had been established in the nineteenth century.

Before moving back in time (in chapter 2), let us identify the main issues at stake in the present-day debate on the question of intervening or not intervening militarily for humanitarian reasons. Putting aside the proverbial question of whether 'violent means can ever serve humanitarian ends, ${ }^{36}$ today's debate includes six main questions and at least three secondary ones.

The first question concerns the legality-legitimacy spectrum. Is legality through UN authorization indispensable? Is non-authorized intervention by definition illegal or is it perhaps legal given an alternative reading of the UN Charter ${ }^{37}$ Can intervention be condoned if it appears legitimate even though it is technically illegal, as the Independent International Commission on Kosovo concluded in its detailed report? ${ }^{38}$ Another tack is the contention that one is faced with a complex legal problem ${ }^{39}$ which may or may not be resolved on an ad hoc basis. 
A second question is where to place the threshold for intervening with or without UN authorization: on systematic human rights violations (such as systematic discrimination akin to apartheid or 'internal colonialism'), on something more grave, such as so-called egregious crimes (i.e. ethnic cleansing, war crimes, crimes against humanity), or only at the level of mass extermination and genocide ${ }^{40}$

A third issue is in which cases to intervene (with or without UN authorization): in a protracted internal war (Liberia, Syria), in a Hobbesian 'war of all against all' (Somalia), a separatist war (Kosovo) or only to put an end to one-sided onslaught (Rwanda), or in all four cases?

A fourth problem is abuse (wrong intentions and ulterior motives) and how it can be checked, if at all. UN authorization, collective intervention and intergovernmental supervision may do the trick but what if they are not forthcoming? And even if they are, they may still be seen as suspect, for the permanent members of the Security Council (as in the case of the Concert of Europe in the nineteenth century) can hardly be counted upon - or live up - to being the moral consciousness of the world. A related factor is the presence of tangible interests as motives and how they can be reconciled with humanitarian motives and intentions, especially since 'saving strangers' on its own is unlikely to provoke intervention. ${ }^{41}$

Another question is timing. Should intervention take place only after the exhaustion of all peaceful means (i.e. as a last resort) or should there be early, anticipatory intervention and preventive deployment once egregious crimes have been spotted, such as ethnic cleansing, so as to forestall a humanitarian disaster (the Kosovo model) and to avoid greater use of military force later, even though early intervention would be more difficult to justify internationally? ${ }^{42}$

There is also the need for a reasonable estimate of a successful outcome, that is, of attaining the humanitarian goals, avoiding 'noble intentions and bloody results', ${ }^{43}$ with few deaths of civilians and little destruction of infrastructure (sparse 'collateral damage'). ${ }^{44}$ There is also the related issue of ensuring that less damage is done by intervening than by not intervening. ${ }^{45}$

The three secondary questions concern: a quick exit strategy or a longer stay for fear that the bloodbath and anarchy will resume; ${ }^{46}$ how many casualties of 'our soldiers' are acceptable; ${ }^{47}$ and the fact that the intervening states are by definition more powerful, which smacks of the powerful bullying the weak under a smokescreen of righteousness. ${ }^{48}$

The recent tendency of advocates of humanitarian intervention is to borrow from the well developed 'just war' doctrine of the Middle Ages and Renaissance (see chapter 2), with the criteria for a just war remodelled to fit modern conditions. The following 'just war' criteria are all regarded as essential for a humanitarian intervention to be contemplated: right authority, in the sense of 'legitimate authority' and not simply legal (factual) authority, which also alludes to 'failed 
states' as illegitimate and not worthy of sovereignty; ${ }^{49}$ just cause (massive suffering); right intention (humanitarian motives genuine and not a ruse); last resort; proportional means (good over harm); and a reasonable prospect of success, leading to a 'just peace'. ${ }^{50}$

\section{Notes}

1 B. Jahn, 'Humanitarian Intervention - What's in a Name?', International Politics, 49:1 (2012), 36.

2 A. Roberts, 'Humanitarian War: Military Intervention and Human Rights', International Affairs, 69:3 (1993), 429.

3 C. Schmitt, The Concept of the Political (New Brunswick: Rutgers University Press, 1976, translated from the German, with Introduction and notes by G. Schwab) [1932], 54.

4 Ibid., 54.

5 M. J. Smith, 'Humanitarian Intervention: An Overview of the Ethical Issues', Ethics and International Affairs, 12:1 (1998), 73.

6 M. Walzer, 'The Politics of Rescue', Social Research, 62:1 (1995), 59.

7 D. C. Hendrickson, 'In Defense of Realism: A Commentary on Just and Unjust War', Ethics and International Relations, 11 (1997), 19-53; M. Wesley, 'Toward a Realist Ethics of Intervention', Ethics and International Affairs, 22:1 (2008), 55-72.

8 N. Chomsky, A New Generation Draws the Line: Kosovo, East Timor and the Standards of the West (New York: Verso, 2001).

9 T. Ali (ed.), Masters of the Universe? NATO's Balkan Crusade (New York: Verso, 200o).

10 A. Orford, Reading Humanitarian Intervention: Human Rights and the Use of Force in International Law (Cambridge: Cambridge University Press, 2003).

11 A. Anghie, Imperialism, Sovereignty and the Making of International Law (Cambridge: Cambridge University Press, 2004), 274-308.

12 C. Douzinas, Human Rights and Empire: The Political Philosophy of Cosmopolitanism (Abingdon: Routledge-Cavendish, 2007).

13 J. Habermas, 'Bestiality and Humanity: A War on the Border Between Legality and Morality', Constellations, 6:3 (1999), 263-72.

14 Walzer, 'The Politics of Rescue', 53-66; M. Walzer, 'The Argument About Humanitarian Intervention', Dissent, 49:1 (2002), 29-37.

15 See S. Hoffmann, 'The Politics and Ethics of Military Intervention', Survival, 37:4 (1995-96), 34-6; Smith, 'Humanitarian Intervention', 70-5; T. Allen and S. Syan, 'A Right to Interfere? Bernard Kouchner and the New Humanitarianism', Journal of Development, 12 (2000), 825, 828-36, 840; G. J. Bass, Freedom's Battle: The Origins of Humanitarian Intervention (New York: Vintage Books, 2009), 11-24.

16 See e.g. Hoffmann, 'The Politics and Ethics of Military Intervention', 29, 37-41; Smith, 'Humanitarian Intervention', 63-79; N. J. Wheeler, 'Legitimating Humanitarian Intervention: Principles and Procedures', Melbourne Journal of International Law, 2:2 (2001), $550-67$.

17 M. Walzer, Just and Unjust Wars (New York: Basic Books, 1977), 101-8.

18 For a low threshold see W. M. Reisman, 'Sovereignty and Human Rights in Contemporary International Law', American Journal of International Law, 84:4 (1990), 866-76; A. D’Amato, 'The Invasion of Panama Was a Lawful Response to Tyranny', American 
Journal of International Law, 84:2 (1990), 516-24; F. R. Tesón, 'Eight Principles for Humanitarian Intervention', Journal of Military Ethics, 5:2 (2006), 95-100, 105-6. For a high threshold, a 'spike test', see T. Farer, 'Cosmopolitan Humanitarian Intervention: A Five-Part Test', International Affairs, 19:2 (2005), 215-19.

19 They included some major figures from an older generation, such as Lauterpacht, Guggenheim, de Visscher, Reisman, McDougal and Jessup, as well as Lillich, D’Amato, Moore, Chilstrom, Levitin, Umozurike, Sornarajah and Tesón.

20 N. J. Wheeler, Saving Strangers: Humanitarian Intervention in International Society (Oxford: Oxford University Press, 2000), 64 n.43.

21 M. Leifer, 'Vietnam's Intervention in Kampuchea: The Rights of States Versus the Rights of People', in I. Forbes and M. Hoffman (eds), Political Theory, International Relations, and the Ethics of Intervention (Basingstoke: Macmillan, 1993), 145-56; F. Hassan, 'Realpolitik in International Law: After Tanzanian-Ugandan Conflict, "Humanitarian Intervention" Reexamined', Willamette Law Review, 17 (1981), 897; Wheeler, Saving Strangers, 65-71, 80-106; M. Akehurst, 'Humanitarian Intervention', in H. Bull (ed.), Intervention in World Politics (Oxford: Clarendon Press, 1984), 95-9; S. Chesterman, Just War or Just Peace? Humanitarian Intervention and International Law (Oxford: Oxford University Press, 2001), 71-4, 77-80.

22 B. D. Jones, “Intervention without Borders": Humanitarian Intervention in Rwanda, 1990-94', Millennium: Journal of International Studies, 24:2 (1995), 225, 230-1.

23 See H. Howe, 'Lessons of Liberia: ECOMOG and Regional Peacekeeping', International Security, 21:3 (1997), 145-76.

24 For the international law debate see: R. A. Falk, 'Kosovo, World Order, and the Future of International Law', American Journal of International Law, 93:4 (1999), 847-57; B. Simma, 'NATO, the UN and the Use of Force: Legal Aspects', European Journal of International Law, 10 (1999), 1-22; A. Cassese, 'Ex injuria jus oritur: Are We Moving Towards International Legitimation of Forcible Humanitarian Countermeasures in the World Community?, European Journal of International Law, 10, (1999), 23-30; L. Henkin, 'Kosovo and the Law of "Humanitarian Intervention"', American Journal of International Law, 93:4 (1999), 824-8; R. Wedgewood, 'NATO's Campaign in Yugoslavia', American Journal of International Law, 93:4 (1999), 828-34. More generally see Independent International Commission on Kosovo, Kosovo Report: Conflict, International Response, Lessons Learned (Oxford: Oxford University Press, 2000); A. Schnabel and R. Thakur (eds), Kosovo and the Challenge of Humanitarian Intervention (Tokyo: United Nations University Press, 2000).

25 N. J. Wheeler and T. Dunne, 'East Timor and the New Humanitarian Interventionism', International Affairs, 77:4 (2001), 805-37.

26 T. G. Weiss, 'The Sunset of Humanitarian Intervention? The Responsibility to Protect in a Unipolar Era', Security Dialogue, 25:2 (2004), 135.

27 J. Pattison, 'The Ethics of Humanitarian Intervention in Libya', Ethics and International Affairs, 25:3 (2011), 271-7.

28 K. Annan, 'Two Concepts of Sovereignty', The Economist, 18 September 1999, 49.

29 Press release SG/SM/7136, GA/9596 (20 September 1999), 2.

30 R. Thakur, 'Outlook: Intervention, Sovereignty and the Responsibility to Protect: Experiences from ICISS', Security Dialogue, 33:3 (2002), 325.

31 G. Evans and M. Sahnoun, 'The Responsibility to Protect', Foreign Affairs, 1:6 (2002), 99-100; T. G. Weiss, 'R2P after 9/11 and the World Summit', Wisconsin International Law Journal, 24:3 (2006), 741-60. 
32 International Commission on Intervention and State Sovereignty (ICISS), Responsibility to Protect (Ottawa: International Development Research Centre, 2001), 16-18; Thakur, 'Outlook', 327-8.

33 C. Stahn, 'Responsibility to Protect: Political Rhetoric or Emerging Legal Norm?', American Journal of International Law, 101:1 (2007), 102.

34 A. J. Bellamy, 'Whither the Responsibility to Protect? Humanitarian Intervention and the 2005 World Summit', Ethics and International Affairs, 20:2 (2006), 146-7, 151-2, 167.

35 J. Welsh, 'Civilian Protection in Libya: Putting Coercion and Controversy Back into RtoP', Ethics and International Affairs, 25:3 (2011), 255-62.

36 Wheeler, 'Legitimating Humanitarian Intervention', 556.

37 For the alternative reading see e.g. W. D. Verwey, 'Humanitarian Intervention Under International Law', Netherlands International Law Review, 32 (1985), 357-418, especially 406-18; C. F. Amerasinghe, 'The Conundrum of Recourse to Force - To Protect Persons', International Organizations Law Review, 3 (2006), 7-53, especially 37-9, 47-53.

38 Independent International Commission on Kosovo, Kosovo Report, 2.

39 I. Hurd, 'Is Humanitarian Intervention Legal? The Rule of Law in an Incoherent World', Ethics and International Affairs, 25:3 (2011), 293-313.

40 M. J. Bazyler, 'Reexamining the Doctrine of Humanitarian Intervention in Light of the Atrocities in Kampuchea and Ethiopia', Stanford Journal of International Law, 23 (1987), 598-601; Hoffmann, 'The Politics and Ethics of Military Intervention', 37-8; D. Fisher, 'The Ethics of Intervention', Survival, 36 (1994), 51-9; Farer, 'Cosmopolitan Humanitarian Intervention', 215-17; M. Fixdal and D. Smith, 'Humanitarian Intervention and Just War', Mershon International Studies Review, 42:2 (1998), 296-9.

41 R. B. Lillich, 'Forcible Self-Help by States to Protect Human Rights', Iowa Law Review, 53 (1967-68), 53; Walzer, Just and Unjust Wars, 101-4; Wheeler, 'Legitimating Humanitarian Intervention', $238-9$.

42 Hoffmann, 'The Politics and Ethics of Military Intervention', 44; Fixdal and Smith, 'Humanitarian Intervention and Just War', 301-2.

43 M. Ignatieff, 'The Seductiveness of Moral Disgust', Social Research, 62:1 (1995), 78.

44 G. Levy, 'The Case for Humanitarian Intervention', Orbis, 37:4 (1993), 624; A. Roberts, 'The Crisis in U.S. Peacekeeping', Survival, 36 (1994), 109.

45 Fixdal and Smith, 'Humanitarian Intervention and Just War', 305; Farer, 'Cosmopolitan Humanitarian Intervention', 219; B. Parekh, 'Rethinking Humanitarian Intervention', International Political Science Review, 18:1 (1997), 67.

46 Walzer, 'The Politics of Rescue', 56-7, 61; Hoffmann, 'The Politics and Ethics of Military Intervention', 41, 43.

47 Walzer, 'The Politics of Rescue', 58-9; Hendrickson, 'In Defense of Realism', 46.

48 Hassan, 'Realpolitik in International Law', 910.

49 Fixdal and Smith, 'Humanitarian Intervention and Just War', 291-2; A. Coates, 'Humanitarian Intervention: A Conflict of Traditions', in T. Nardin and M. S. Williams (eds), Humanitarian Intervention (New York: New York University Press, 2006), 62-3.

50 J. B. Hehir, 'Expanding Military Intervention: Promise or Peril?', Social Research, 62:1 (1995), 46-8; Fixdal and Smith, 'Humanitarian Intervention and Just War', 283-312; Wheeler, 'Legitimating Humanitarian Intervention', 550-67; Thakur, 'Outlook', 332-3; G. Reichberg and H. Syse, 'Humanitarian Intervention: A Case of Offensive Force?', Security Dialogue, 33:3 (2002), 309-22; J. Boyle, 'Traditional Just War Theory and Humanitarian Intervention', in Nardin and Williams (eds), Humanitarian Intervention, $31-57$. 